\title{
Spatially and temporally variable catchment-wide denudation rates - clues from the Alps
}

\author{
Reto Grischott
}

\author{
E-Mail: \\ University: \\ reto.grischott@phys.ethz.ch \\ Supervisors: \\ Laboratory for Ion Beam Physics, ETH Zürich, Switzerland \\ Florian Kober, Sean D. Willett, Susan Ivy-Ochs, Rainer Wieler, Matthias Hinderer \\ Dissertation online: http://e-collection.library.ethz.ch/view/eth:49001 (abstract only). Fulltext will be available in May 2017.
}

Catchment-wide denudation rates (CWDR) can be obtained by measuring in-situ produced terrestrial cosmogenic nuclides in alluvial sediments (GRANGER et al. 1996). For alpine catchments, such "modern" samples commonly provide a mean estimate of denudation over the last two millennia, but their sensitivity to recording climatic fluctuations on the Holocene time-scale is limited. In order to overcome these temporal limitations of modern CWDRs, paleo-CWDRs were derived from sediment cores collected in valley fills. The main goal of the thesis was therefore to establish ${ }^{10} \mathrm{Be}$ records of paleo-CWDRs in alpine settings, in order to determine controls on denudation over the Holocene and the latest Pleistocene. Additionally, for one setting it was aimed to independently validate the cosmogenic paleo-CWDRs by a sediment budget approach.

A major part of the thesis was dedicated to the first goal of establishing ${ }^{10} \mathrm{Be}$ records of paleo-CWDRs in the European Alps. The approach entailed selecting two alpine catchments with different altitude ranges, in order to compare and test them for climatic impacts on denudation. The lower altitudinal range $(1200-2400 \mathrm{~m})$ is represented by the Seebach catchment in the eastern Austrian Alps (GRIschотT et al., submitted). The geomorphological analysis indicates that that sediment released from the upper hillslopes above $\sim 2400 \mathrm{~m}$ are geomorphologically disconnected to the trunk stream for the Holocene. Repeated sediment samples from the active stream during three years were analysed to obtain estimates about modern CWDRs. Paleo-CWDRs were obtained from ${ }^{10} \mathrm{Be}$ measurements derived from a previously drilled $160 \mathrm{~m}$-long lake sediment core, which contains the Late Glacial to present signal. The combined record of paleo and modern CWDRs show three different stages of denudation. The Late Glacial to the Early Holocene period is characterized by a decreasing trend of anomalously high CWDRs of $\sim 7 \mathrm{~mm} / \mathrm{yr}$ towards typical alpine rates of $\sim 0.6 \mathrm{~mm} / \mathrm{yr}$, which can explained by the incorporation of low-dosed, glacial sediments found in the sediment core (Fig. 1A). The temporal trend of our ${ }^{10} \mathrm{Be}$ data indicate paraglacial sediment fluxes for the Seebach Valley from at least $\sim 15$ to $\sim 7 \mathrm{kyr}$ BP which show a similar pattern like the paraglacial cycle postulated by $\mathrm{CHURCH} \&$ RYDER (1972). Holocene CWDRs for the last 7 kyrs correlate with the frequency of extreme precipitation events and anti-correlate with mean annual temperature. Minimal CWDRs of $\sim 0.4 \mathrm{~mm} / \mathrm{yr}$ were found during the Middle Holocene, and are best explained by weaker hillslope erosion induced by rare extreme precipitation events, dense vegetation cover and thus stabilized soils on the hillslope (Fig. 1B). In the Late Holocene, CWDRs quickly raised again and then remained at a constant rate of $0.65-0.85 \mathrm{~mm} / \mathrm{yr}$, due to increased hillslope erosion likely caused by frequent extreme precipitation events and lower timberlines and vegetation cover (Fig. 1C).

The second study area is the Fedoz catchment in the eastern Swiss Alps, which represents the higher altitudinal range (2000-3000 m). Samples from three alluvial sediment cores integrating over the last $6 \mathrm{kyr}$, and a three-year time series of samples from the active stream were analysed for ${ }^{10} \mathrm{Be}$ (GRISchotT et al. 2016). Derived paleo-CWDRs show a surprisingly constant temporal trend of $0.7 \mathrm{~mm} / \mathrm{yr}$ for the last $6 \mathrm{kyr}$. We propose that the elongated alluvial floodplain in the Fedoz Valley may act as an efficient sediment buffer on the Holocene time-scales (Fig. 2). Sediments from glacial and hillslope erosion containing low and high ${ }^{10} \mathrm{Be}$ concentrations, respectively, are mixed and their variability in ${ }^{10} \mathrm{Be}$ is dampened during transport. Therefore, variations in the ${ }^{10} \mathrm{Be}$ signal that may be produced by Holocene climate fluctuations are only poorly transferred to the outlet and are, thus, not recorded in the ${ }^{10} \mathrm{Be}$ record of the studied sediment archive. Despite this loss of signal variability, it is proposed that the buffered ${ }^{10} \mathrm{Be}$ signal still could be meaningfully interpreted as a robust, longer-term denudation rate.

The data from the Fedoz catchment have additionally been used to independently validate the cosmogenic denudation rates by a sediment budget approach (EINSELE \& HINDERER 1998). Geophysical measures of the subaquatic and 


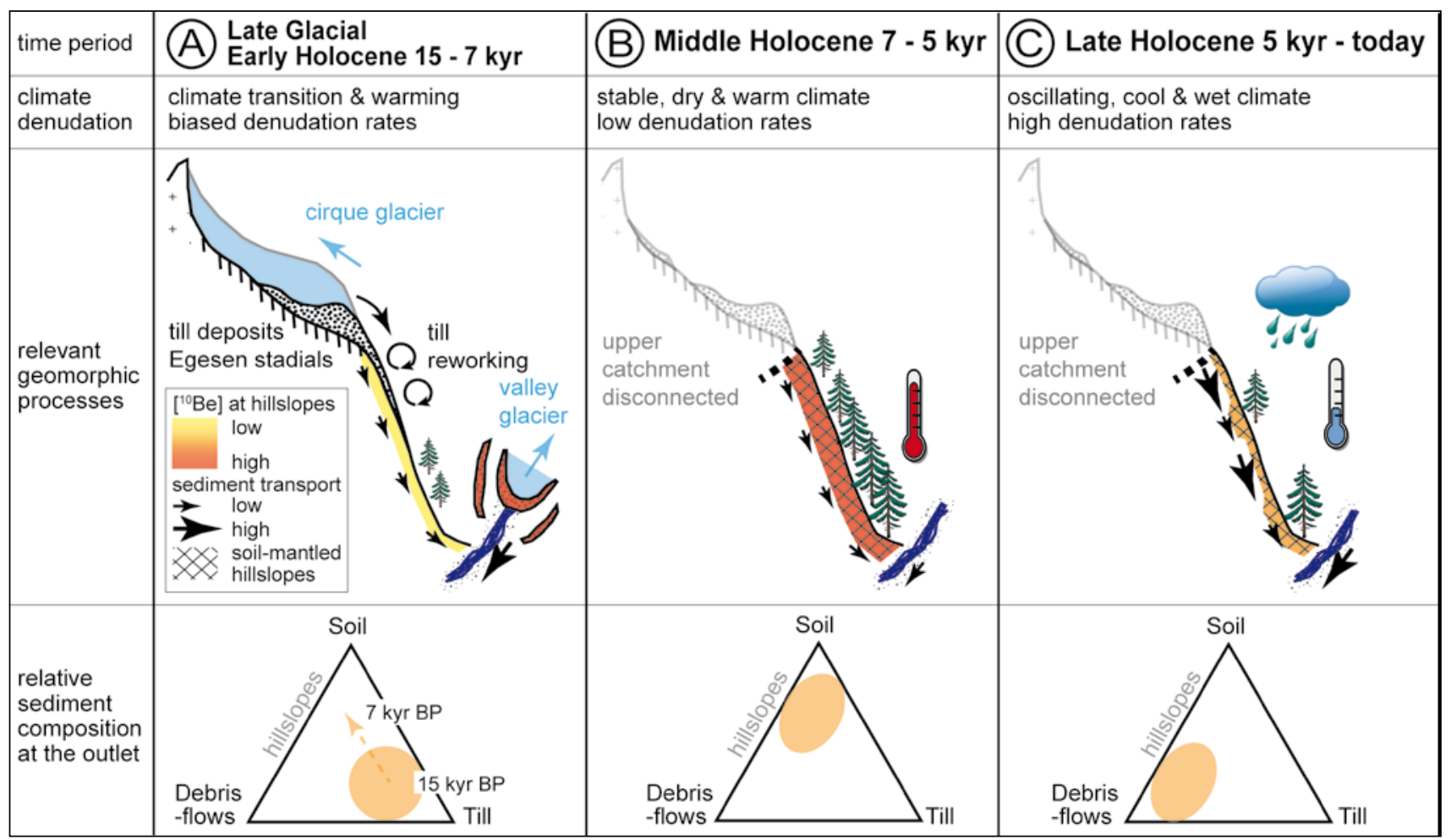

Fig. 1: Schematic, temporal evolution of the ${ }^{10}$ Be hillslope profile, hillslope cover and interpreted sediment fluxes for the Holocene. During the Late Pleistocene and Early Holocene (A), reworking of the glacial sediments and zeroed hillslopes due to glacial erosion leads to low ${ }^{10} B e$ concentrations of exported sediments. The Mid-Holocene $(B)$ is characterized by rare flood events and warm temperatures leading to the development of soil and vegetation cover and related stabilization of hillslopes. Later, increase of the flood frequency and colder temperatures during the Late Holocene (C) leads to higher hillslope erosion and sediment flux.

subaerial delta slope were used to define the sediment volumes (Fig. 2). The sediment cores from both parts were taken to validate the data as ground truth and integrate them in a chronostratigraphical framework. However, due to several technical limitations of the geophysical techniques and a lack of sediment cores with reliable age depth models, the uncertainty of the derived sediment budget is significant. Mean denudation rates based on the sediment budget model are a magnitude lower during the Middle Holocene compared with the cosmogenic CWDRs. This offset might result from sediment storage caused by a strongly reduced transport capacity of the Fedoz River, likely due to a decreased occurrence of flood events. During the Late Holocene, CWDRs calculated from the sediment budget are half of the cosmogenic nuclide derived, which may imply that less storage in the catchment occurred. Frequent flood events might have increased the fluvial transport capacity and provided a stronger connection between the river and hillslopes.

Altogether, this work shows that great progress was made in isolating climate control on denudation over a

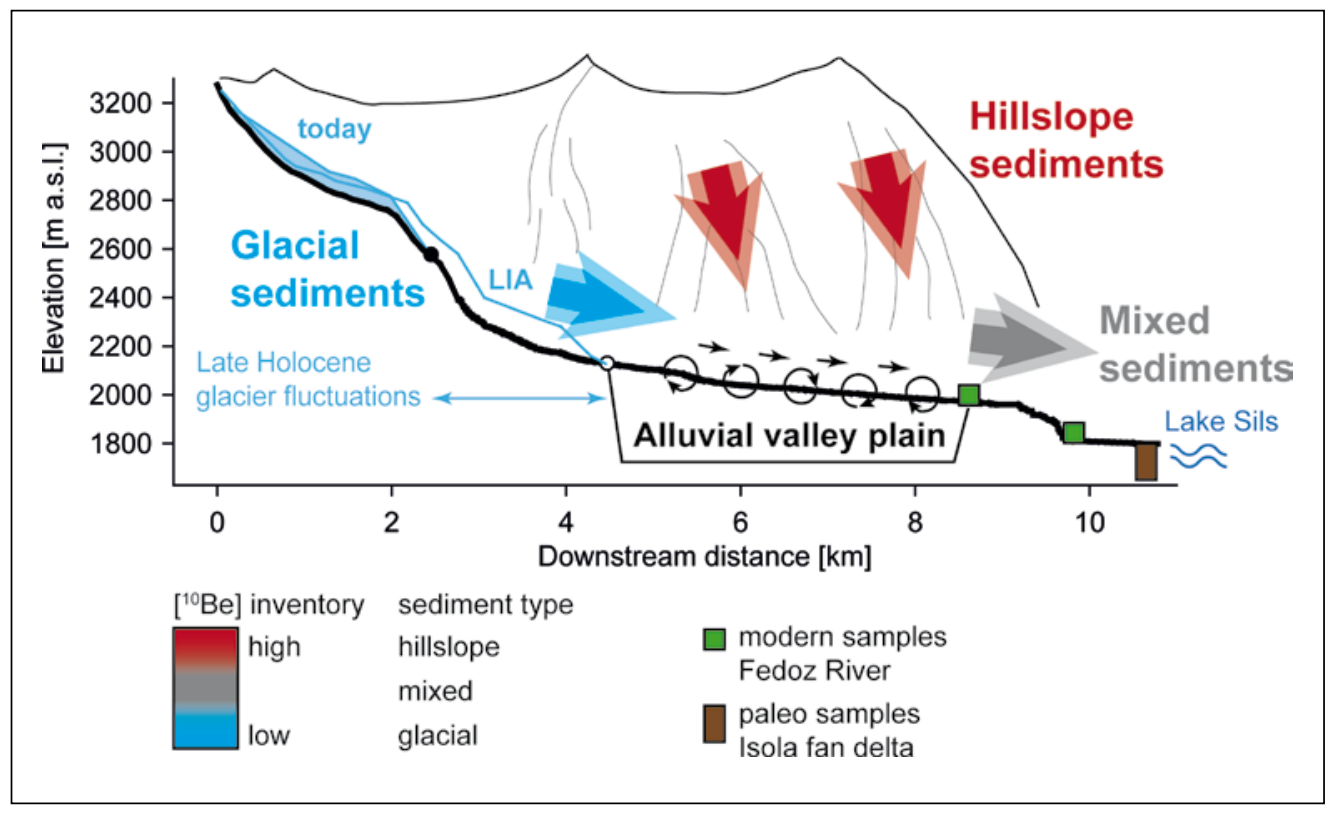

Fig. 2: Schematic sketch of contributing sediment sources and their assumed ${ }^{10}$ Be signature in the Fedoz catchment shown along with the channel length profile of the Fedoz River, the locations of the ${ }^{10} \mathrm{Be}$ samples and sediment cores. The alluvial flood plain is suggested to act as an important sediment buffer and mixing system (indicated by the retrograde arrows). The sediment budget is estimated based on sediment volumes of the delta plain and slope. (Figure modified from GRISCHOTT et al. 2016) 
$10^{3}-10^{4}$ year timescale by the extended analysis of ${ }^{10} \mathrm{Be}$ in sediment archives of various catchments. Furthermore, it has been proven once more that ${ }^{10} \mathrm{Be}$ can serve as an ideal sediment tracer even for settings or time periods where this proxy is not representative for hillslope erosion.

\section{References}

Church, M., Ryder, J.M. (1972): Paraglacial sedimentation - A consideration of fluvial processes conditioned by glaciation. - Geological Society of America Bulletin 83, 3059-\&.

EinSELE, G., Hinderer, M. (1998): Quantifying denudation and sedimentaccumulation systems (open and closed lakes): basic concepts and first results. - Palaeogeography Palaeoclimatology Palaeoecology $140,7-21$.

Granger, D.E., Kirchner, J.W. \& Finkel, R. (1996): Spatially averaged long-term erosion rates measured from in situ-produced cosmogenic nuclides in alluvial sediment. - Journal of Geology 104, 249-257.

Grischott, R., Kober, F., Lupker, M., Hippe, K., Ivy-Ochs, S., Hajdas, I., SAlcher, B. \& Christl, M. (2016): Constant denudation rates in a high alpine catchment for the last 6 kyrs. - Earth Surf Processes, 10.1002/esp.4070

Grischott, R., Kober, F., Lupker, M., Reitner, J.M., Drescher-SchneiDER, R., Hajdas, I., Christl, M. \& Willett, S.D. (submitted): Millennial scale variability of denudation rates for the last 15 kyrs inferred from the detrital ${ }^{10} \mathrm{Be}$ record of lake Stappitz in the Hohe Tauern massif, Austrian Alps. - The Holocene. 